\title{
A Contribution to the Economical and Ecological Assessment of Electromobiles
}

\author{
Š. Čorňák*, P. Braun, V. Neumann \\ Department of Combat and Special Vehicles, University of Defence in Brno, Czech Republic \\ * Corresponding author: stefan.cornak@unob.cz
}

DOI: $10.2478 / \mathrm{v} 10158-012-0002-7$

\begin{abstract}
Six vehicles of the same class ( 3 with combustion engines, 3 electromobiles) were compared and the results are that the total life cycle costs (LCC) of the electromobiles are distinctively lower. The relation between fuel usage and carbon dioxide production $\left(\mathrm{CO}_{2}\right)$ is shown in the second part of the paper. The vehicles with the combustion engine meet maximum carbon dioxide production $\left(\mathrm{CO}_{2}\right)$ outline requirements (the requirement of the EU committee is $120 \mathrm{~g} / \mathrm{km}$ ) with a maximum fuel usage of $5.1 \mathrm{l} / 100 \mathrm{~km}$. Electromobiles meet maximum carbon dioxide production $\left(\mathrm{CO}_{2}\right)$ outline requirements with a maximum fuel usage of $4.51 / 100 \mathrm{~km}$.
\end{abstract}

KEY WORDS: life cycle costs (LCC), electromobiles, ecological economy, fuel usage, carbon dioxide production.

\section{INTRODUCTION}

The number of vehicles on the roads is constantly growing. At the end of the year 2009 there were more than 6.4 million insured vehicles registered in the database of the Czech insurer's office (Finance.cz, 2009). Rice in process of the fuels, adverse effects of exhaust pollutants, the restriction of "dirty" vehicles' entry to town centers (Adac, 2009), new EU limits on $\mathrm{CO}_{2}$ production in vehicles with gas-engines (Směrnice komise 1999/100/ES, 1999) and electric power were the most dominant aspects which have initiated the use of electromobiles. It can be expected that the present consumer will not only consider the type, comfort, and technical parameters, but also the economical and ecological properties of the vehicles during their selection. From the aforesaid it is evident that it would be useful to set the general procedure to economical and ecologic efficiency classification.

\section{RANKING OF VEHICLES' ECONOMICAL EFFICIENCY}

For the ranking of vehicles' economical efficiency it is necessary to choose the right economical parameters and make the cost items selection. 


\subsection{Choosing the right economical parameters}

The right economical parameter (for the vehicles' economical efficiency) could be cumulative expenses $\mathrm{N}$. In the case where the vehicles have a different lifetime (range) to the outage, the right economical parameter could be the specific costs $\mathrm{n}$. The specific costs $\mathrm{n}$ could be expressed by the following formula:

$$
N=\frac{n}{s_{v}}
$$

where: $\mathrm{n}$ - specific comparative costs $[\mathrm{CZK} / \mathrm{km}], \mathrm{N}$ - expense items (cumulative costs) $[\mathrm{CZK}], \mathrm{s}_{\mathrm{v}}$ - lifetime to the outage $[\mathrm{km}]$.

\subsection{Selection of the cost items}

The basic guideline for ranking a vehicles' economical efficiency is the standard (ČSN 300-3$3,1997)$. According to this standard life cycle costs (LCC) are divided into the six following stages - the stage of concept and establishment of the requirements; the stage of design and development; the stage of production; the stage of installation; the stage of operation and maintenance; and the removal stage. It is logical that each period is characterized by the economic costs.

It is not necessary, during the comparison of the economic efficiency of the vehicles, to calculate with the overall costs of the vehicles' life cycle in the stage of operation and maintenance. For a comparison of the critical cost items a quick and basic orientation suffices. The critical costs items of this stage are the initial costs $\left(\mathrm{N}_{\mathrm{POR}}\right)$ and the costs of ownership $\left(\mathrm{N}_{\mathrm{VL}}\right)$. These costs can be expressed mathematically as follows:

$$
N=N_{P O R}+N_{V L}
$$

A more accurate and detailed separation of each vehicle's conclusion would be attained by an evaluation of additional costs items. However, a huge range of costs items is not useful, as this procedure becomes too complex and is often inefficient.

The critical cost items of the ownership costs of electromobiles are the price of the vehicle NV, electric power costs (accumulator charging) $\mathrm{N}_{\mathrm{DB}}$, accumulator costs $\mathrm{N}_{\mathrm{B}}$, tire costs $\mathrm{N}_{\mathrm{P}}$, preventive maintenance costs $\mathrm{N}_{\mathrm{PU}}$, and corrective maintenance costs $\mathrm{N}_{\mathrm{NU}}$.

The cost items of electromobiles $\mathrm{N}_{\mathrm{EL}}$ can be expressed mathematically as follows:

$$
N_{E L}=N_{V}+N_{D}+N_{B}+N_{P}+N_{P U}+N_{N U}
$$

The critical cost items of the ownership costs of vehicles with a combustion engine are the price of the vehicle $\mathrm{N}_{\mathrm{V}}$, fuel costs $\mathrm{N}_{\mathrm{F}}$, lubricant costs $\mathrm{N}_{\mathrm{O}}$, starting accumulator costs $\mathrm{N}_{\mathrm{A}}$, tire costs $\mathrm{NP}$, preventive maintenance costs $\mathrm{N}_{\mathrm{PU}}$, and corrective maintenance costs (repair) $\mathrm{N}_{\mathrm{NU}}$.

The cost items of vehicles with a combustion engine $\mathrm{N}_{\mathrm{SM}}$ can be expressed mathematically as follows:

$$
N_{S M}=N_{V}+N_{F}+N_{O}+N_{P}+N_{A}+N_{P U}+N_{N U}
$$


Note: Some other cost items (toll costs, technical control costs) are, for vehicles in the same category, identical. Therefore, it is possible to ignore these items during economical comparison and thereby the solving of the economical comparison is simpler.

The following formulas (Čorňák, Braun, Petř́íček, 2005), (Čorňák, Braun, 2009), (Havlíček, 1989), (Kočár, 2004), (Vintr, 2000) could be used for quantitative determination of these items:

- electric power costs (accumulator charging) for the whole life cycle:

$$
N_{D}=\frac{i_{B} \cdot U_{B} \cdot Q_{B} \cdot p_{E L} \cdot s_{v}}{1000 \cdot \eta_{B} \cdot s_{D B}}[\mathrm{CZK}]
$$

where: $\mathrm{s}_{\mathrm{DB}}$ - trailing throttle with fully charged accumulators on one charging cycle $[\mathrm{km}]$, $\mathrm{i}_{\mathrm{B}}-$ number of accumulators [no], $\mathrm{U}_{\mathrm{B}}-$ voltage of one accumulator [V], $\mathrm{Q}_{\mathrm{B}}-$ accumulator capacity [A.h], $\mathrm{t}_{\mathrm{NB}}$ - charging time for one charging cycle [h], $\mathrm{p}_{\mathrm{EL}}$ - electric power cost $\left[\mathrm{CZK} / \mathrm{kW}\right.$.hour], $\mathrm{s}_{\mathrm{V}}-$ lifetime (technical life $=100000 \mathrm{~km}$ ), $\eta_{\mathrm{B}}-$ energy losses, $\eta_{\mathrm{B}}=0,9$ (charger and accumulator heating losses).

- accumulator costs $\mathrm{N}_{\mathrm{B}}$ for the whole life cycle:

$$
N_{B}=\frac{s_{v}}{\bar{s}_{Z B}} \cdot i_{B} \cdot p_{B}[\mathrm{CZK}]
$$

where: $\mathrm{p}_{\mathrm{B}}-$ price of one accumulator $[\mathrm{CZK}]$,

- average lifetime of the accumulator:

$$
\bar{s}_{Z B}=c_{N B} \cdot s_{D B}[\mathrm{~km}]
$$

where: $\mathrm{c}_{\mathrm{NB}}-$ number of charging cycles per one accumulator.

- fuel costs $\mathrm{N}_{\mathrm{P}}$ :

$$
N_{F}=\frac{N_{F}}{100} \cdot p_{F} \cdot s_{v}[\mathrm{CZK}]
$$

where: $\mathrm{N}_{\mathrm{F}}$ - specific fuel consumption $[1 / 100 \mathrm{~km}], \mathrm{p}_{\mathrm{F}}-$ fuel price [CZK/1],

- lubricant costs $\mathrm{N}_{\mathrm{OL}}$ :

$$
N_{O}=\frac{N_{O}}{100} \cdot p_{O} \cdot s_{v}[\mathrm{CZK}]
$$

where: $\mathrm{N}_{\mathrm{O}}$ - specific lubricant consumption $[1 / 100 \mathrm{~km}], \mathrm{p}_{\mathrm{o}}$ - lubricant price $[\mathrm{CZK} / 1]$, 
- starting accumulator costs $\mathrm{N}_{\mathrm{A}}$ :

$$
N_{A}=\frac{i_{A} \cdot p_{A} \cdot s_{v}}{\bar{s}_{A}}[\mathrm{CZK}]
$$

where: $i_{\mathrm{A}}$ - number of starting accumulators [no], $\mathrm{p}_{\mathrm{A}}$ - price of the one starting accumulator [CZK/no], $\bar{s}_{A}$ - average accumulator lifetime $[\mathrm{km}]$,

- tire costs $\mathrm{N}_{\mathrm{PN}}$ :

$$
N_{P}=\frac{i_{P} \cdot p_{P} \cdot s_{v}}{\bar{s}_{P}}[\mathrm{CZK}]
$$

where: $\mathrm{i}_{\mathrm{P}}-$ number of vehicle tires [no], $\mathrm{p}_{\mathrm{P}}-$ price of one tire [CZK/no], $\bar{S}_{P}-$ average tire lifetime $[\mathrm{km}]$,

- preventive maintenance costs $\mathrm{N}_{\mathrm{PU}}$ :

$$
N_{P U}=\frac{s_{v}}{s_{P U}} \cdot \bar{N}_{P U}[\mathrm{CZK}]
$$

where: $\bar{s}_{P U}$ - average running between preventive maintenance $[\mathrm{km}], \bar{N}_{P U}$ - average costs of one preventive maintenance [CZK],

- corrective maintenance costs (repair) $\mathrm{N}_{\mathrm{NU}}$ :

$$
N_{N U}=\frac{\left(s_{v}-s_{z}\right)}{\bar{s}_{N U}} \cdot \bar{N}_{N U}[\mathrm{CZK}]
$$

where: $\bar{s}_{N U}$ - average running time between failures [km], $\bar{N}_{N U}$ - average costs of one corrective maintenance (repair) $[\mathrm{CZK}], \mathrm{S}_{\mathrm{Z}}$ - running of the vehicle within the guaranty $[\mathrm{km}]$.

2.3 Implementation of the designed model for the evaluation of the vehicle's economic efficiency

Six karts were chosen (3 with combustion engines M1, M2, M3; 3 electromobiles E1, E2, E3) for a practical implementation of the designed model. They were karts from the same category, and, therefore, it is supposed they have similar running conditions.

The initial values of the electromobiles E1, E2 and E3 are shown in tables no. 1 and 2. The initial values of the vehicles with combustion engines are shown in tables no. 3 and 4. 
Table 1: Technical data of the electromobiles.

\begin{tabular}{|c|c|c|c|}
\hline \multirow{2}{*}{ Specification } & \multicolumn{3}{|c|}{ Vehicle values: } \\
\hline & E1 & E2 & E3 \\
\hline number of accumulator $-i_{B}[$ no] & 8 & 8 & 2 \\
\hline voltage of one accumulator $-\mathrm{U}_{\mathrm{B}}[\mathrm{V}]$ & 6 & 6 & 24 \\
\hline accumulator capacity $-\mathrm{Q}_{\mathrm{B}}[\mathrm{Ah}]$ & 190 & 190 & 300 \\
\hline charging time for one charging cycle $-\mathrm{t}_{\mathrm{NB}}[\mathrm{h}]$ & \multicolumn{3}{|c|}{8} \\
\hline number of the charging cycle of the one accumulator $-\mathrm{c}_{\mathrm{B}}[\mathrm{no}]$ & \multicolumn{3}{|c|}{1400} \\
\hline $\begin{array}{l}\text { trailing throttle with fully charged accumulators on one charging cycle - } \\
t_{\mathrm{EB}}[\mathrm{km}]\end{array}$ & 70 & 70 & 90 \\
\hline energy losses during the charging $-\eta_{B}[-]$ & \multicolumn{3}{|c|}{0.9} \\
\hline Number of the tires $-i_{\mathrm{P}}[\mathrm{no}]$ & \multicolumn{3}{|c|}{4} \\
\hline average tire lifetime $\bar{s}_{P}[\mathrm{~km}]$ & \multicolumn{3}{|c|}{50000} \\
\hline average running to preventive maintenance $-\bar{s}_{P U}[\mathrm{~km}]$ & \multicolumn{3}{|c|}{$10000 *$} \\
\hline average running time between the corrective maintenance $-\bar{s}_{N U}[\mathrm{~km}]$ & \multicolumn{3}{|c|}{$20000 * *$} \\
\hline running of the vehicle within the guaranty $-s_{z}[\mathrm{~km}]$ & \multicolumn{3}{|c|}{10000} \\
\hline running to the removal (lifetime) $-s_{v}[\mathrm{~km}]$ & \multicolumn{3}{|c|}{100000} \\
\hline
\end{tabular}

Note: Some items are not complex observed during operation (namely the items of corrective maintenance). These items were determined using expert judgment.

Table 2: Economical specifications of the electromobiles.

\begin{tabular}{|l|c|c|c|}
\hline \multicolumn{1}{|c|}{ Specification } & \multicolumn{3}{c|}{ Vehicle values: } \\
\cline { 2 - 4 } & E1 & E2 & E3 \\
\hline vehicle price $N_{v}[\mathrm{CZK}]$ & 436000 & 468000 & 568000 \\
\hline vehicle price without accumulators $N_{v}[\mathrm{CZK}]$ & 339000 & 372000 & 423000 \\
\hline price of the one accumulator $p_{B}[\mathrm{CZK} / \mathrm{no}]$ & 12000 & 12000 & 72500 \\
\hline electric power price $p_{E L}[\mathrm{CZK} / \mathrm{kW} \cdot \mathrm{hour}]$ & \multicolumn{3}{|c|}{3500} \\
\hline price of the one additive accumulator $p_{B}[\mathrm{CZK}]$, & \multicolumn{3}{|c|}{25000} \\
\hline price of the one tire $p_{P}[\mathrm{CZK} /$ no $]$ & \multicolumn{3}{|c|}{$5000^{* *}$} \\
\hline $\begin{array}{l}\text { average costs to preventive maintenance } \bar{N}_{P U} \\
{[\mathrm{CZK}]}\end{array}$ & \multicolumn{3}{|c|}{} \\
\hline $\begin{array}{l}\text { average cost of one corrective maintenance (repair) } \bar{N}_{N U} \\
{[\mathrm{CZK}]}\end{array}$ & \multicolumn{3}{|c|}{} \\
\hline
\end{tabular}

Next specifications are published in the publication (Čorňák \& Braun, 2009).

Note:

- prices are mentioned in Czech crowns without VAT,

- notes in some data:

* recommended by the vehicle producer (Čorňák, Braun, 2009).

** judgment (double preventive maintenance).

$Z M$ - vehicle with spark ignition engine,

${ }^{V M}$ - vehicle with diesel engine. 
Table 3: Technical data of the vehicles (combustion engine).

\begin{tabular}{|l|c|c|c|}
\hline \multirow{2}{*}{ Specification } & \multicolumn{3}{c|}{ Vehicle values: } \\
\cline { 2 - 4 } & $\mathrm{M} 1{ }^{\mathrm{ZM}}$ & $\mathrm{M} 2{ }^{\mathrm{VM}}$ & $\mathrm{M} 3{ }^{\mathrm{VM}} 4 \mathrm{x} 4$ \\
\hline fuel usage $N_{F}[1 / 100 \mathrm{~km}]$ & 10 & 8 & 14 \\
\hline lubricant usage $N_{O}[1 / 100 \mathrm{~km}]$ & 0.1 & 0.15 & 0.2 \\
\hline number of starting accumulators $i_{A}[\mathrm{no}]$ & 1 & 1 & 1 \\
\hline accumulator average lifetime $\bar{S}_{A}[\mathrm{~km}]$ & 30000 & 30000 & 30000 \\
\hline number of the tires $-\mathrm{i}_{\mathrm{P}}[\mathrm{no}]$ & 4 & 4 & 4 \\
\hline tire average lifetime $\bar{S}_{P}[\mathrm{~km}]$ & 33000 & 33000 & 33000 \\
\hline $\begin{array}{l}\text { average running between preventive maintenance - } \\
\bar{s}_{P U}[\mathrm{~km}]\end{array}$ & $2000^{*}$ & $4000^{*}$ & $4000^{*}$ \\
\hline average running time between failures $-\bar{s}_{N U}[\mathrm{~km}]$ & $4000^{* *}$ & $8000^{* *}$ & $8000^{* *}$ \\
\hline running of the vehicle within guaranty $-s_{z}[\mathrm{~km}]$ & 10000 & 10000 & 10000 \\
\hline running to the removal (lifetime) $-s_{v}[\mathrm{~km}]$ & 100000 & 100000 & 100000 \\
\hline
\end{tabular}

Table 4: Economical specification of the vehicles (combustion engine).

\begin{tabular}{|l|c|c|c|}
\hline \multicolumn{1}{|c|}{ Specification } & \multicolumn{3}{c|}{ Vehicle values: } \\
\cline { 2 - 4 } & M1 ZM & M2 VM & $\begin{array}{c}\text { M3 } \\
4 \times 4\end{array}$ \\
\hline vehicle price $N_{v}[\mathrm{CZK}]$ & 345000 & 420000 & 500000 \\
\hline one litre fuel price $p_{F}[\mathrm{CZK}]$ & 25 & 27 & 27 \\
\hline one litre lubricant price $p_{O}[\mathrm{CZK}]$ & \multicolumn{3}{|c|}{300} \\
\hline one starting accumulator price $p_{A}[\mathrm{CZK} / \mathrm{no}]$ & \multicolumn{3}{|c|}{6000} \\
\hline one tire price $p_{P}[\mathrm{CZK} /$ no] & \multicolumn{3}{|c|}{$500^{*}$} \\
\hline average costs to preventive maintenance $\bar{N}_{P U}[\mathrm{CZK}]$ & $000^{* *}$ \\
\hline $\begin{array}{l}\text { average costs of one corrective maintenance (repair) } \\
\bar{N}_{N U}[\mathrm{CZK}]\end{array}$ & \multicolumn{3}{|c|}{} \\
\hline
\end{tabular}

The values of the cumulative costs comparison of the electromobiles E1, E2 and E3 are shown in figure 1. The values of the cumulative costs comparison of vehicles with a combustion engine M1, M2 and M3 are shown in figure 2. There is a relative comparison of the specific costs of the electromobiles (E1, E2, E3) and vehicles with a combustion engine (M1, M2, M3) shown in figure 3.

It is possible to make the following conclusion from the results:

- the operational costs of the electromobiles during their lifetime (running $100000 \mathrm{~km}$ ) forms about $22 \%$ of the overall vehicle price,

- the operational costs of the vehicle M1 forms about $122 \%$, of the vehicle M2 about $103 \%$ and of vehicle M3 (4x4) about $121 \%$ of the overall vehicle price, 
- the specific costs of accumulator charging are $0.29 \mathrm{CZK} / \mathrm{km}$ (vehicles E1, E2) and $0.36 \mathrm{CZK} / \mathrm{km}$ (vehicle E3),

- specific fuel costs are $2.50 \mathrm{CZK} / \mathrm{km}$ (vehicle M1), $2.16 \mathrm{CZK} / \mathrm{km}$ (vehicle M2) and $3.78 \mathrm{CZK} / \mathrm{km}$ (vehicle M3 4x4),

- electromobiles overall costs during their lifetime (running $100 \quad 000 \quad \mathrm{~km}$ ) are about $5.97 \mathrm{CZK} / \mathrm{km}$, the overall costs of vehicles with a combustion engine are about $9.10 \mathrm{CZK} / \mathrm{km}$.

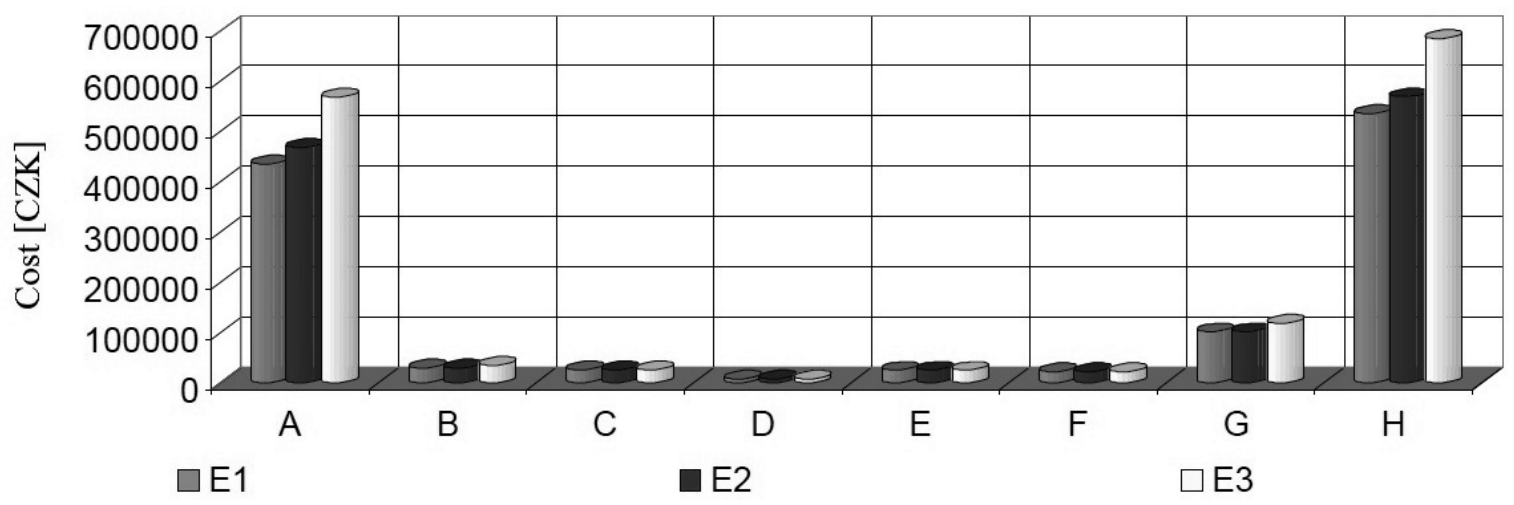

Figure 1: Cumulative costs comparison of the electromobiles.

Where: $\quad \mathrm{A}-$ vehicle price, $\mathrm{B}-$ electric power price, $\mathrm{C}-$ tire price, $\mathrm{D}-$ additive accumulator price, $\mathrm{E}$ - preventive maintenance price, $\mathrm{F}$ - corrective maintenance price, $\mathrm{G}$ - operating costs, $\mathrm{H}$ - overall costs during lifetime.

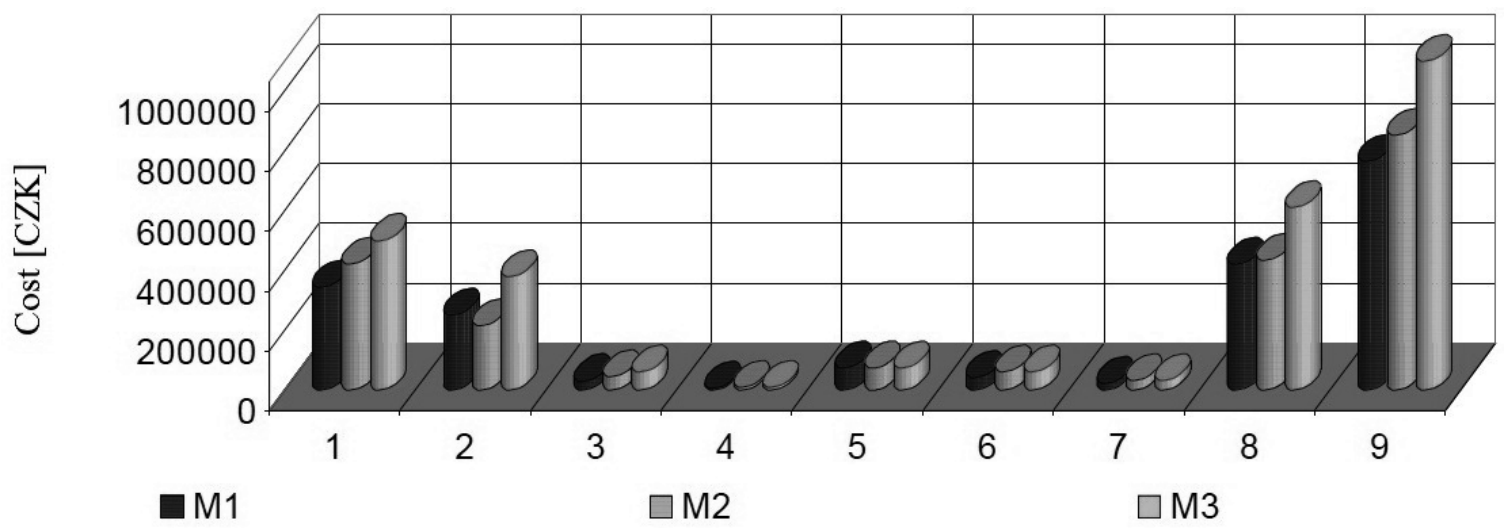

Figure 2: Cumulative costs comparison of vehicles with a combustion engine.

Where: $\quad 1$ - vehicle price, 2 - fuel price, 3 - lubricant price, 4 - starting accumulator price, 5 - tire price, 6 - preventive maintenance price, 7 - corrective maintenance price, 8 - operating costs, 9 - overall costs during lifetime. 


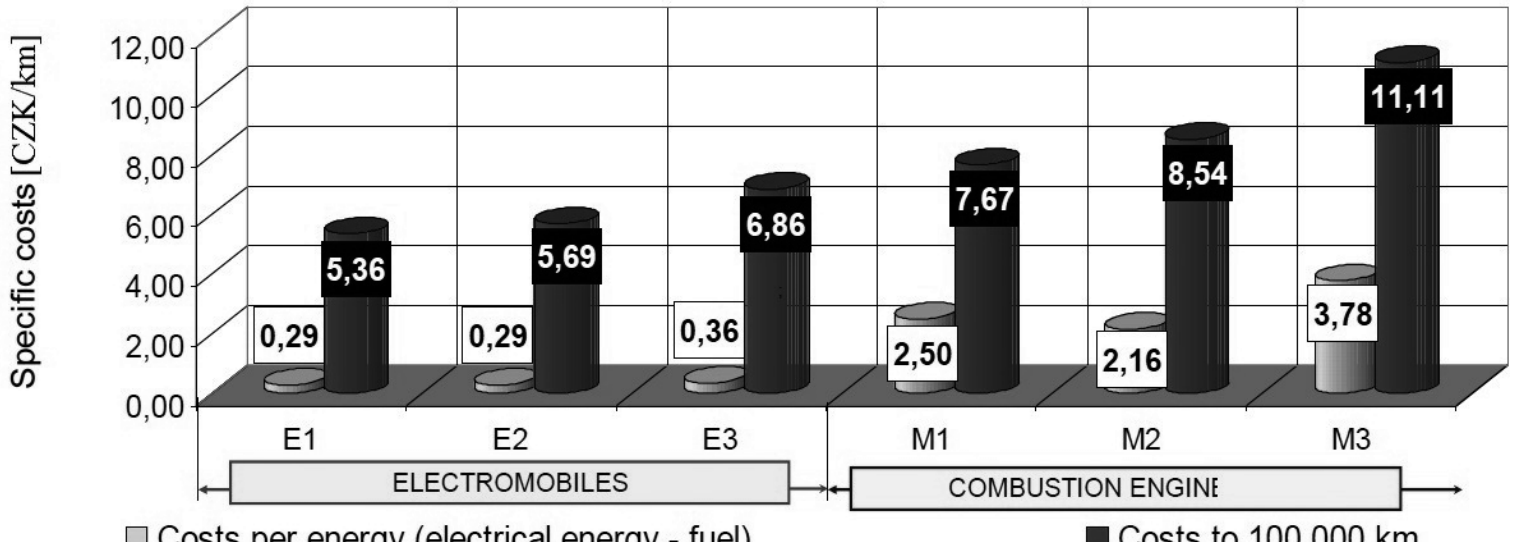

$\square$ Costs per energy (electrical energy - fuel)

Costs to $100000 \mathrm{~km}$

Figure 3: Relative comparison of the specific costs of electromobiles and vehicles with a combustion engine.

The result of the analysis is that the overall operational costs are lower than in vehicles with a combustion engine. The reason for this is that there are no demands for POL and other material exchanging in electromobiles (lubricants, coolant, clutch, exhaust...).

The overall results of the relative comparison of the vehicles in the publication are published (Čorňák, Braun, 2009).

\section{ECOLOGICAL RANKING OF THE VEHICLES}

The main advantage of electromobiles is their ecological operation. For electromobile operation there are no taxes for exhaust-emission measurement. Electromobiles could be freed from road-traffic taxing and insurance costs could be lower. The lifetime of the break lining is generally longer, due to recuperation breaking (breaking is one of the polluters). On the opposite side vehicles with a combustion engine are a source of noxious emissions, especially carbon monoxide (CO), hydrocarbons (THC), nitrogen oxide, and solid particles (PM) (ES 78/2009, 2009). These dangerous substances are a result of the imperfect combustion of fuel in the engine.

During the combustion of fuel in the engine additional pollutants are produced, such as carbon dioxide $\left(\mathrm{CO}_{2}\right)$. Carbon dioxide is not a dangerous pollutant, but it is a significant source of global warming (NRC, 2008). This is a reason why the present discussion focuses on new EU limits on $\mathrm{CO}_{2}$. These limits could be obtained from the year 2012 and they could be solved from the average vehicle distribution of the one vehicle producer.

Carbon dioxide production has a direct relation to fuel usage. The basic source of comparison for the relation between carbon dioxide production and fuel usage could be used norm (Směrnice komise 1999/100/ES). According to this norm $\mathrm{CO}_{2}$ production is measured during the testing cycle, which simulates operation within and outside of the city.

This cycle is described in the 1 st addition of the 3rd supplement of the directions 70/220/EHS (about carbon dioxide production and fuel usage of vehicles).

The formulas for calculating the fuel usage from the measuring emissions in this norm are also published (Směrnice komise 1999/100/ES). If we know the real fuel usage FC, fuel density $\mathrm{D}, \mathrm{CO}$ and $\mathrm{THC}$, we can formulate the relation specific $\mathrm{CO}_{2}$ emission from the fuel usage through the following formulas: 
- vehicles with petrol engine used petrol:

$$
m_{\mathrm{CO}_{2}}=23,489 . F C_{B A}[\mathrm{~g} / \mathrm{km}]
$$

- vehicles with petrol engine used gas (LPG):

$$
m_{C O_{2}}=16,259 \cdot F C_{L P G}[\mathrm{~g} / \mathrm{km}]
$$

- vehicles with petrol engine used NG:

$$
m_{\mathrm{CO}_{2}}=21,132 \cdot F C_{\mathrm{NG}}[\mathrm{g} / \mathrm{km}]
$$

- vehicles with diesel engine:

$$
m_{\mathrm{CO}_{2}}=26,640 \cdot F C_{N M}[\mathrm{~g} / \mathrm{km}]
$$

where: $\quad \mathrm{FC}_{\mathrm{BA}}-$ fuel usage (petrol) $[1 / 100 \mathrm{~km}], \mathrm{FC}_{\mathrm{LPG}}-$ gas usage (LPG) $[1 / 100 \mathrm{~km}]$, $\mathrm{FC}_{\mathrm{NG}}$ - fuel usage (NG) $[\mathrm{m} 3 / 100 \mathrm{~km}], \mathrm{FC}_{\mathrm{NM}}$ - fuel usage (diesel) [1/100km].

On the basis of the above-mentioned formulas $(14-17)$ a graph was constructed, shown in figure 4. From the results we can make the following conclusion: vehicles witha combustion engine meet the maximum carbon dioxide production $\left(\mathrm{CO}_{2}\right)$ outline requirement (requirement of the $\mathrm{EU}$ committee is $120 \mathrm{~g} / \mathrm{km}$ ) with a maximum fuel usage of $5.1 \mathrm{l} / 100 \mathrm{~km}$ (with a petrol engine), $7.4 \mathrm{l} / 100 \mathrm{~km}$ (with an LPG engine), $5.7 \mathrm{l} / 100 \mathrm{~km}$ (with a NG engine) and $4.51 / 100 \mathrm{~km}$ (with a diesel engine).

\section{CONCLUSION}

This paper is focused on an evaluation of the economic and ecological efficiency of vehicles. Only some basic methours and their practical applications are presented in this paper, due to the limited length of this paper. Therefore only six vehicles were compared, but the method and procedures used are general and could be used generally for an evaluation of a vehicle's economic efficiency (from the user's point of view).

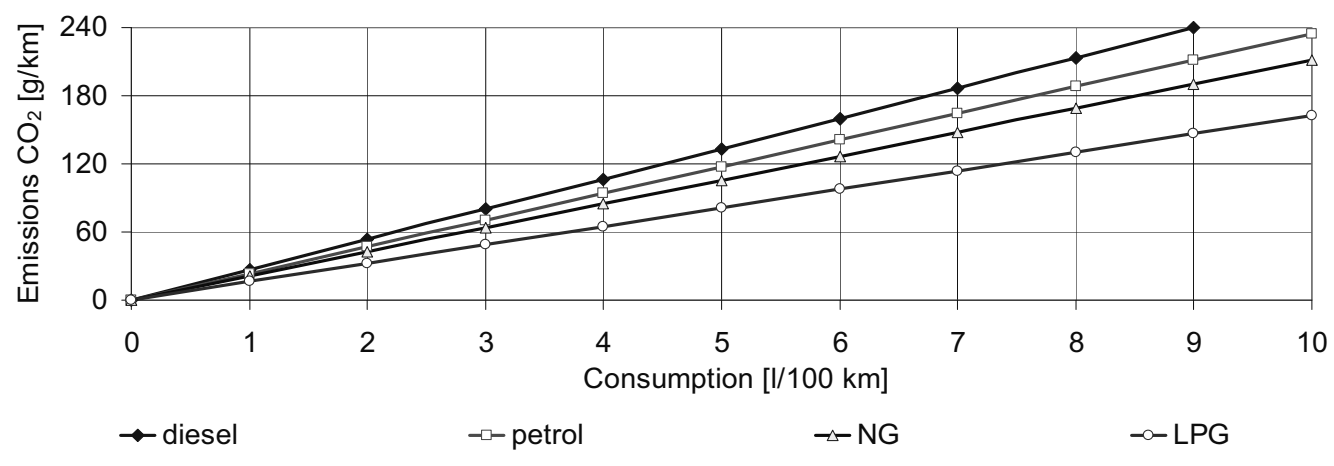

Figure 4: Graphical dependence of the calculated values of $\mathrm{CO}_{2}$ on fuel usage. 


\section{ACKNOWLEDGMENT}

The paper has been written within the research project of the development K-202 department, University of Defence in Brno.

\section{REFERENCES}

Adac [online], 2009. Retrieved from: www.adac.de/plaketten.

Čorňák, Š., Braun, P., Petř́ček, O., 2005. Možnosti hodnocení ekonomické efektivnosti vozidel. In Sborník Univerzity obrany - řada B, č. 1. Brno: Univerzita obrany. ISSN 1211-1023. (in Czech)

Čorňák, Š., Braun, P., 2009. Posouzení multicar [Odborná studie]. Brno: Univerzita obrany. (in Czech)

ČSN IEC 300-3-3, 1997. Management spolehlivosti. Část 3: Návod k použití. Oddíl 3: Analýza nákladi̊ životního cyklu. (in Czech)

ES 78/2009, 2009. Nařízení evropského parlamentu a rady (ES) č. 78/2009 ze dne 14. ledna 2009 o schvalování typu motorových vozidel. (in Czech)

Finance.cz [online], 2009. Retrieved from: http://www.finance.cz/pojisteni/statistika/pocetpojistenych-vozidel/ (in Czech)

Havlíček, J., 1989. Provozní spolehlivost strojů. Praha: SNTL. (in Czech)

Kočár, J., 2004. Automobil osobni terénní-OAT [Marketingová analýza]. (in Czech)

NRC, 2008. Understanding and Responding to Climate Change. Board on Atmospheric Sciences and Climate, US National Academy of Sciences, p. 4.

Směrnice komise 1999/100/ES ze dne 15. prosince 1999, kterou se přizpůsobuje technickému pokroku směrnice Rady 80/1268/EHS o emisích oxidu uhličitého a spotřebě paliva motorových vozidel. (in Czech)

Vintr, Z., 2000. Hodnocení nákladů životního cyklu vozidla. In Sborník Mezinárodní conference při př́ležitosti 50 let založeni Fakulty strojní [CD-ROM]. Ostrava: VŠB-TU. (in Czech) 